UDC: 547.818:547.489.4:542.91:615.359

\title{
Screening of antioxidant and anti-inflammatory activities among thiopyrano[2,3-d]thiazoles
}

\author{
A. V. Lozynskyi, D. V. Kaminskyy, Kh. B. Romanchyshyn, \\ N. G. Semenciv, V. V. Ogurtsov, I. O. Nektegayev, R. B. Lesyk \\ Danylo Halytsky Lviv National Medical University \\ 69, Pekarska Str., Lviv, Ukraine, 79010 \\ dr_r_lesyk@org.lviv.net,roman.lesyk@gmail.com
}

\begin{abstract}
The aim of present research was the investigation of antioxidant and antiexudative activities of the series of thiopyrano[2,3- $d]$ thiazoles synthesized based on cinnamic acid amides. Methods. Organic synthesis; spectral methods; free radical scavenging assay (DPPH test); evaluation of antiexudative activity (carrageenan oedema model in rats). Results. The evaluation of the free radicals scavenging activity and antiexudative activity of series of the 2-oxo-5-phenyl-7-aryl(hetaryl)-3,7-dihydro- $2 H$-thiopyrano[2,3- $d$ ] thiazole-6-carboxylic acid amides was performed. Among the tested compounds, rel-(5R,6S,7S)- $N$ - (4methylphenyl)-7-(4-methylphenyl)-2-oxo-5-phenyl-3,5,6,7-tetrahydro-2H-thiopyrano[2,3- $d$ ] thiazole-6carboxamide possessed the highest level of both activities. The experimental data most probably indicate a pronounced effect of methyl groups (phenyl fragments) on the realization of the anti-inflammatory and antioxidant effects and allow a suggestion about the antiradical mechanism of anti-inflammatory activity of the target compounds. Conclusions. The anti-inflammatory and free radicals scavenging activities of some tiopyrano[2,3- $d]$ thiazoles have been established and the most active compounds were identified. Some findings of the structure-activity relationship were set up.
\end{abstract}

Key w or d s: thiopyrano[2,3- $d]$ thiazoles, antioxidant activity, antiexudative activity.

\section{Introduction}

The oxidant and free radical processes are in focus of the research. The reactive oxygen and nitrogen species such as hydroxyl and peroxyl radicals, the superoxide anion etc., are constantly produced as a result of metabolic reactions in living systems and are involved in numerous processes, both normal and pathological [1]. Living systems are protected from the oxidative damage by these reactive species by enzymes (for instance, superoxide dismutase, glutathione peroxidase) and by antioxidant compounds such as ascorbic acid, tocopherols, and carotenoids, etc. [1, 2]. However, when the free-radical production exceeds the antioxidant capacity, these radical species attack macromolecules, thus damaging structural integrity and function of cell membranes, enzymes, and genetic material. A growing body of evidence indicates that various pathological conditions, including cardiovascular disease, arthritis, inflammation, cancer, and Alzheimer's disease are associated, at least in part, with the damaging effects of uncontrolled free-radicals production [3, 4]. Thus, many biologically active compounds, especially natural, may provide the protection against mentioned processes through multiple effects, which are still poorly understood [5-7]. These compounds may act as antioxidants by reacting with free radicals and thus interrupting the propagation of new free radical species, by chelating metal ions, etc. They

\footnotetext{
(C) 2015 A. V. Lozynskyi et al.; Published by the Institute of Molecular Biology and Genetics, NAS of Ukraine on behalf of Biopolymers and Cell. This is an Open Access article distributed under the terms of the Creative Commons Attribution License (http://creativecommons.org/licenses/by/4.0/), which permits unrestricted reuse, distribution, and reproduction in any medium, provided the original work is properly cited
} 

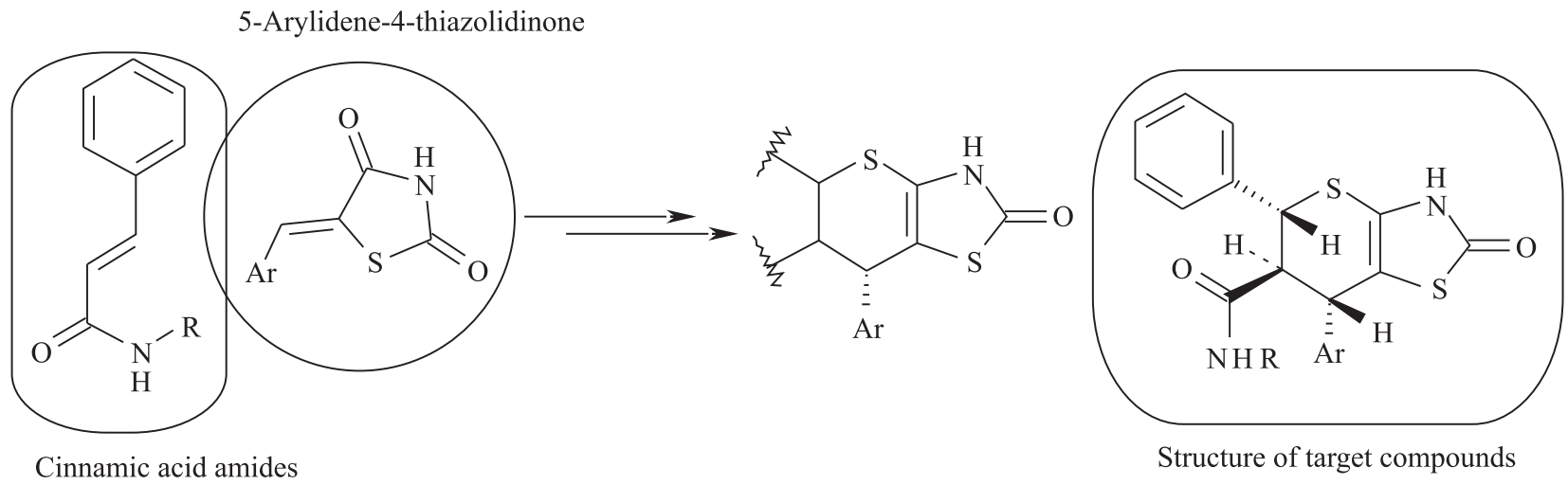

Fig. 1. Background for target compounds design

also may protect against oxidant-mediated inflammation and tissue damage by a virtue of their ability not only to scavenge free radicals but also to inhibit the activation of NF-kB (and possibly other oxidantsensitive transcription factors) [4, 5] and improve certain immune responses [8].

On the other hand, many synthetic heterocycles possess similar biological profiles. For instance, 4-thiazolidinones and related heterocycles showed the antiinflammatory, antitumor, antitrypanosomal, antidiabetic activities, which often are associated with the antioxidant effect [9-11]. Majority of 4thiazolidione-based lead-compounds and drug-candidates belong to the 5-ylidene-4-thiazolidinone subtype and have many advantages in the drug discovery $[9,12-16]$. At the same time, they are also characterized by some negative features. 5-Ylidene-4-thiazolidinones can be considered as electrophilic and potentially reactive substances due to the possible Michael addition of the nucleophilic protein residues to the exocyclic double bond. This characterizes 5-arylidene-4-thiazolidinones as the frequent hitters or pan assay interference compounds that are useless in the modern drug discovery process because of low selectivity [17].

One of the possible solutions of such confusion may be the annealing of the mentioned 5-ylidene-4thiazolidinones into the fused heterocycles. These fused 4-thiazolidinone-based derivatives and in particular thiopyrano[2,3- $d$ ] thiazoles are considered as the cyclic isosteric mimetics of their synthetic precursors - 5-ylidene-4-thiazolidinones without the
Michael accepting functionalities [19,20]. Moreover, design of the mentioned fused heterocycles employed the combination of thiazolidinones and other chemicals including those possessing significant biological activity, for instance cinnamic acid and its derivatives (Fig. 1.), that can be treated as a benefit in the hybride molecules design.

Therefore, as the continuation of our previous studies [19-22] in the field of biologically active fused 4-thiazolidinone-based heterocycles the aim of the manuscript was the search for new compounds with antioxidant and antiexudative activities among thiopyrano $[2,3-d]$ thiazoles.

\section{Materials and Methods}

All chemicals were of the analytical grade and commercially available. All reagents and solvents were used without further purification and drying.

Chemistry. The raw of 2-oxo-5-phenyl-7-aryl(hetaryl)-3,7-dihydro-2H-thiopyrano[2,3- $d$ ] thiazole-6carbocyclic acid amides (1-10) for antioxidant and anti-inflammatory screening was synthesized by us previously (Scheme) [22]. Starting cinnamic acid was transformed into corresponding acid chloride and then converted into appropriate amides. The 5-arylidene-4-thioxo-2-thiazolidinones were synthesized via Knoevenagel condensation of 4-thioxo-2-thiazolidinone with aldehydes (ethanol medium in the presence of ethylenediaminediacetate) [19]. The final phase was the hetero-Diels-Alder reaction, with regioselectively and diastereoselectively yielded target rel-(5R,6S,7S)-2-oxo-5-phenyl-7-aryl(hetaryl)-3,7- 


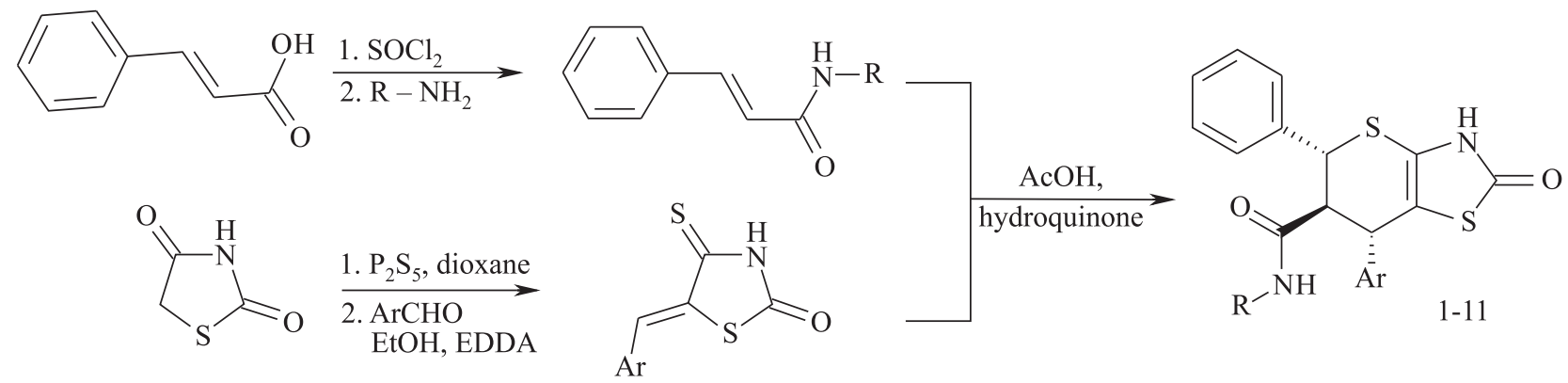

Scheme. General synthetic scheme

dihydro-2H-thiopyrano[2, 3-d] thiazole-6-carbocyclic acid amides.

rel-(5R, 6S, 7S)-N-(4-Methylphenyl)-7-(4methoxyphenyl)-2-oxo-5-phenyl-3,5,6,7-tetrahydro2H-thiopyrano[2,3-d] thiazole-6-carboxamide (11).

A mixture of 5-(4-metoxybenzylidene)-4-thioxo2-thiazolidinone (5 mmol) and $\mathbf{N}$-(4-methylphenyl)3-phenylacrylamide $(5.5 \mathrm{mmol})$ was refluxed for 5 $\mathrm{h}$ with a catalytic amount of hydroquinone (2-3 mg) in $15 \mathrm{~mL}$ of glacial acetic acid and left overnight at rt. The obtained product was collected by filtration, washed with water, methanol, diethyl ether, and recrystallized from the ethanol. Yield: 70\%, mp 234$236{ }^{\circ} \mathrm{C} .{ }^{1} \mathrm{H}$ NMR (400 MHz, DMSO- $\left.d_{6}\right) \delta: 2.16$ (s, $\left.3 \mathrm{H}, \mathrm{CH}_{3}\right), 3.44$ (t, $\left.1 \mathrm{H}, J=10.4 \mathrm{~Hz}, 6-\mathrm{H}\right), 4.30$ (d, 1H, $J=10.4 \mathrm{~Hz}, 7-\mathrm{H}), 4.70$ (d, 1H, $J=10.4 \mathrm{~Hz}, 5-\mathrm{H})$, 6.75 (d, 2H, $J=8.4 \mathrm{~Hz}$, arom.), 6.83 (d, 2H, $J=8.4$ $\mathrm{Hz}$, arom.), 7.32 (d, 2H, J=7.2 Hz, arom.), 7.46 (d, 2H, $J=7.2 \mathrm{~Hz}$, arom.), 9.23 (s, 1H, NH), 11.29 (s, 1H, NH). ${ }^{13} \mathrm{C}$ NMR (100 MHz, DMSO- $\left.d_{6}\right) \delta: 20.3,45.0,48.5$, 55.8, 107.5, 119.1, 119.8, 120.4, 128.3, 128.4, 128.5, 128.6, 130.2, 132.0, 132.7, 134.9, 136.2, 139.3, 167.9, 170.4. Anal.Calcd for $\mathrm{C}_{27} \mathrm{H}_{24} \mathrm{~N}_{2} \mathrm{O}_{3} \mathrm{~S}_{2}, \% \mathrm{C}, 66.37 ; \mathrm{H}$, 4.95; N, 5.73. Found, \%: C, 66.50; H, 4.90; N, 5.62.

Pharmacology. The synthesized compounds were evaluated for their antioxidant (DPPH free radical scavenging assay) and antiexudative activity on the carrageenan oedema model in rats.

Free radical scavenging assay. The scavenging effect of the synthesized compounds on the DPPH $(1,1-$ diphenyl-2-picrylhydrazyl radical) was evaluated according to the Blois method [23]. The solution of DPPH $(150 \mu \mathrm{M})$ in ethanol $(4 \mathrm{~mL})$ was mixed with the tested compound or ascorbic acid as the referent compound
$(250 \mu \mathrm{M})$ solution in ethanol $(0.2 \mathrm{~mL})$. The reaction mixture was thoroughly mixed and incubated $30 \mathrm{~min}$ at rt. in the dark. A decrease in absorbance of the mixture (in comparision with the sample which contains only DPPH solution) was measured at $540 \mathrm{~nm}$. All tests and analyses were undertaken in three replicates and the results averaged. The scavenging activity was calculated: $(\%)=\left(\left[\mathrm{A}_{\mathrm{DPPH}}-\mathrm{A}_{\mathrm{s}}\right] / \mathrm{A}_{\mathrm{DPPH}}\right) \times 100 \%$, where: $\mathrm{A}_{\mathrm{DPPH}}$ is an absorbance of DPPH solution, $\mathrm{A}_{\mathrm{s}}$ is an absorbance of the tested sample.

Antiexudative assay. For antiexudative test the male rats weighing 180-220 g were used. The carragenan-induced hind paw oedema was produced by the method of Winter et al. [24]. Carrageenan solution $(1.0 \%$ in sterile $0.9 \% \mathrm{NaCl})$ was injected subcutaneosly into the subplanar region of the hind paw ( $0.1 \mathrm{~mL}$ to each paw) $1 \mathrm{~h}$ after administration of the test compound. The synthesized compounds were intraperitoneally injected in a dose $100 \mathrm{mg} / \mathrm{kg}$ (in saline solution with one drop of Tween- $\left.80^{\mathrm{TM}}\right)$. Diclofenac sodium $(10 \mathrm{mg} / \mathrm{kg}$ ) and ketorolac tromethamine $(10 \mathrm{mg} / \mathrm{kg})$ were used as reference compounds. Control rats received only saline solution with one drop of Tween- $80^{\mathrm{TM}}$. The hind paw volume was measured with an electronic onkograph immediately before and $4 \mathrm{~h}$ after carrageenan injection. The effect of test compounds on a decrease of paw oedema was compared with that control. The antiexudative activity was expressed as a decrease of rats paw oedema and was given in percentage.

\section{Results and Discussion}

The structure of new thiopyrano[2,3- $d$ ] thiazoles (fig. 2 ) was designed based on the cinnamic acids deriva- 
<smiles>O=C(Nc1ccccn1)[C@H]1[C@H](c2cccs2)Sc2[nH]c(=O)sc2[C@H]1c1ccccc1</smiles><smiles>[R]NC(=O)[C@H]1[C@@H](c2ccc(Cl)cc2)Sc2[nH]c(=O)sc2[C@H]1c1ccccc1</smiles><smiles>[R]NC(=O)[C@H]1[C@@H](c2ccc(C)cc2)Sc2[nH]c(=O)sc2[C@H]1c1ccccc1</smiles>

$\mathbf{R}=$

2<smiles>Cc1ccc(O)cc1</smiles>

3,6<smiles>Cc1ccc(C(=O)ON)cc1</smiles>

4,7

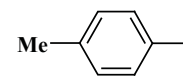

5,8

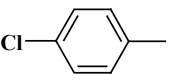<smiles>Cc1ccc([C@H]2c3sc(=O)[nH]c3S[C@H](c3ccccc3)[C@H]2C(=O)N2CCOCC2)cc1</smiles><smiles>O=C(Nc1ccc(Cl)cc1)[C@H]1[C@@H](c2ccc(O)cc2)Sc2[nH]c(=O)sc2[C@H]1c1ccccc1</smiles><smiles>COc1ccc([C@H]2c3sc(=O)[nH]c3S[C@H](c3ccccc3)[C@H]2C(=O)Nc2ccc(C)cc2)cc1</smiles>

Fig. 2. The structure of compounds involved into the study

Table 1. Antioxidant activity of thiopyrano[2,3-d] thiazoles

\begin{tabular}{|c|c|c|}
\hline Compound & $\begin{array}{c}\text { Absorbance } \\
\text { of a sample }\end{array}$ & Inhibition, \% \\
\hline 4 & $0.750 \pm 0.016$ & 3.90 \\
6 & $0.748 \pm 0.014$ & 4.04 \\
7 & $0.354 \pm 0.006$ & 54.57 \\
8 & $0.748 \pm 0.015$ & 4.11 \\
9 & $0.739 \pm 0.016$ & 5.27 \\
11 & $0.742 \pm 0.015$ & 4.86 \\
Ascorbic acid & $0.533 \pm 0.012$ & 31.70 \\
\hline
\end{tabular}

Table 2. Antiexudative activity of the tested of thiopyrano[2,3-d] thiazoles

\begin{tabular}{|c|c|c|}
\hline Compound & $\begin{array}{c}\text { Paw oedema } \\
\text { volume, } \%\end{array}$ & $\begin{array}{c}\text { Inhibition of paw } \\
\text { edema over control, \% }\end{array}$ \\
\hline- & $96.2 \pm 3.78$ & - \\
1 & $86.2 \pm 4.32$ & 10.4 \\
2 & $85.3 \pm 4.21$ & 11.3 \\
3 & $57.6 \pm 2.80$ & 40.1 \\
4 & $63.4 \pm 3.11$ & 34.1 \\
5 & $69.2 \pm 3.40$ & 28.0 \\
6 & $80.4 \pm 4.06$ & 16.4 \\
7 & $52.4 \pm 2.61$ & 45.5 \\
10 & $64,3 \pm 3.20$ & 33.1 \\
Diclofenac & $54.6 \pm 2.53$ & 43.2 \\
Ketorolac & $56.6 \pm 2.60$ & 41.1 \\
\hline
\end{tabular}

tives and the mentioned 5-ylidene-4-thiazolidinones. The synthetic protocol involved the regioselective and diastereoselective hetero-Diels-Alder reaction. The synthesized compounds were screened for anti-inflammatory and antioxidant activities. There is a thesis that an increase of reactive radical species levels causes the development of inflammation along with the antioxidant effect of many antiinflammatory agents. Therefore, it is apparent that in addition to promoting cytotoxicity, reactive oxygen metabolites may also initiate and/or amplify inflammation via the upregulation of several different genes involved in the inflammatory response, such as those that code for proinflammatory cytokines and adhesion molecules [4].

Consequently, the compounds with antioxidant properties could be expected to offer protection in the inflammation process. It is therefore evident that the treatment of the above mentioned pathophysiologies could benefit from the use of drugs with both antioxidant and anti-inflammatory activities. It has already been proven for a number of commercially available non-steroidal anti-inflammatory drugs (NSAIDs), for example, tolfenamic acid which simultaneously possess radical scavenging properties 
$[25,26]$. Additionally, several thiazolidinone derivatives are also pronounced anti-inflammatory and antioxidant agents and might be an exellent basis in searching for the drug-like molecules [27].

To investigate some aspects of the structure-activity relationship among thiopyrano[2,3-d] thiazoles, the antioxidant activity was assessed by the DPPHfree radicals cavenging assay and summarized in Table 1.

Among the tested compounds the rel-(5R,6S,7S)$\mathrm{N}$-(4-methylphenyl)-7-(4-methylphenyl)-2-oxo-5phenyl-3,5,6,7-tetrahydro-2H-thiopyrano[2,3-d] $[1,3]$ thiazole-6-carboxamide (7) was found to be the most active; for other derivatives, a slight antioxidant activity was observed. The comparison of the activity of compounds bearing different amide fragments (compounds 4, 6, 7 \& 9) allowed the suggestion that the presence of methyl groups (including amide fragment) in compound 7 was crucial for the antioxidant activity realization. The same effect was observed in flavonoids row, where the methyl derivatives were much more active in comparison with the derivatives bearing other substituents [28]. This effect is also associated with improved lipophilicity parameter [29]. Moreover, the presence of electron donating groups (especially methyls) at the aromatic core has previously been shown to influence strongly the redox potential of $\alpha, \beta$-unsaturated aromatic compounds. The altered reduction potential of these compounds has an effect on the lipid peroxidation reactions, in which they can participate, and this, in turn, alters their ability to scavenge deleterious oxy radicals [30]. The replacement of the methyl group in the aryl fragment (position 7 of the main core) (compounds 7, $8 \& 11$ ) to the methoxy group or a halogen atom leads to the loss of activity.

The in vivo anti-inflammatory effect of the tested compounds was assessed by using the functional model of carrageenan-induced rat paw oedema (Table 2).

All tested compounds exhibited different protection against the carrageenan-induced paw edema. The compounds $\mathbf{3}$ and $\mathbf{7}$ were the most active among the tested thiopyrano[2,3- $d$ ] thiazoles. The antiexudative activity comparable to the reference drugs was observed in the compounds with two methyl groups (7) or in the presence of methyl and sulfamoyl groups (3). The presence of other group in the molecule led to a decrease in the activity level. The comparison of anti-radical and anti-inflammatory activities allows us to assume the involvement of antioxidant mode in the development of thiopyrano[2,3- $d]$ thiazoles antiinflammatory action.

\section{Conclusion}

The present study has shown that certain thiopyrano[2,3-d]thiazoles possess low to moderate antiinflammatory and antioxidant activities, whereas the compound 7 was found to be a promising free radicals scavenger. The anti-inflammatory assay led to the identification of two active molecules (compounds $3 \& 7$ ). These compounds constitute an interesting template for the design of new synthetic NSAIDs. Despite that the anti-inflammatory mechanism was not elucidated, the mode of antiinflammatory action of the synthesized compounds seems to be related with their radical scavenging activity.

\section{REFERENCES}

1. Halliwell B. Cell culture, oxidative stress, and antioxidants: avoiding pitfalls. Biomed J. 2014;37(3):99-105.

2. Sies H. Oxidative stress: oxidants and antioxidants. Exp Physiol. 1997;82(2):291-5.

3. Valko M, Rhodes CJ, Moncol J, Izakovic M, Mazur M. Free radicals, metals and antioxidants in oxidative stress-induced cancer. Chem Biol Interact. 2006;160(1):1-40.

4. Conner EM, Grisham MB. Inflammation, free radicals, and antioxidants. Nutrition. 1996;12(4):274-7.

5. Forman HJ, Davies KJ, Ursini F. How do nutritional antioxidants really work: nucleophilic tone and para-hormesis versus free radical scavenging in vivo. Free Radic Biol Med. 2014;66:24-35.

6. Yelisyeyeva OP, Semen KO, Ostrovska GV, Kaminskyy DV, Sirota TV, Zarkovic N, Mazur D, Lutsyk OD, Rybalchenko $K$, Bast A. The effect of Amaranth oil on monolayers of artificial lipids and hepatocyte plasma membranes with adrenalin-induced stress. Food Chem. 2014;147:152-9.

7. Semen KO, den Hartog GJM, Kaminskyy DV, Sirota TV, Maij NGAA, Yelisyeyeva OP, Bast A. Redox modulation by amaranth oil in human lung fibroblasts. Nat Prod Chem Res. 2013; 2(1): 1000122 .

8. Natella F, Nardini M, Di Felice M, Scaccini $C$. Benzoic and cinnamic acid derivatives as antioxidants: structure-activity relation. J Agric Food Chem. 1999;47(4):1453-9. 
9. Lesyk RB, Zimenkovsky BS. 4-Thiazolidones: centenarian history, current status and perspectives for modern organic and medicinal chemistry. Curr Org Chem. 2004; 8(16): 1547-77.

10. Lesyk RB, Zimenkovsky BS, Kaminskyy DV, Kryshchyshyn AP, Havryluk DYa, Atamanyuk DV, Subtel'na IYu, Khyluk DV. Thiazolidinone motif in anticancer drug discovery. Experience of DH LNMU medicinal chemistry scientific group. Biopolym Cell. 2011; 27(2):107-17.

11. Kryshchyshyn A, Kaminskyy D, Grellier P, Lesyk R. Trends in research of antitrypanosomal agents among synthetic heterocycles. Eur J Med Chem. 2014;85:51-64.

12. Aly AA, Brown AB, Abdel-Aziz M, Abuo-Rahma GE-DAA, Radwan MF, Ramadan M, Gamal-Eldeend AM. An efficient synthesis of Thiazolidine-4-ones with antitumor and antioxidant activities. J Heterocycl Chem. 2012;49(4):726-31

13. Kaminskyy $D V$, Lesyk RB. Structure-anticancer activity relationships among 4-azolidinone-3-carboxylic acids derivatives. Biopolym Cell. 2010; 26(2):136-45.

14. Tripathi AC, Gupta SJ, Fatima GN, Sonar PK, Verma A, Saraf SK. 4-Thiazolidinones: the advances continue... Eur J Med Chem. 2014;72:52-77.

15. Jain VS, Vora DK, Ramaa CS. Thiazolidine-2,4-diones: progress towards multifarious applications. Bioorg Med Chem. 2013;21(7):1599-620.

16. Kaminskyy D, Zimenkovsky B, Lesyk R. Synthesis and in vitro anticancer activity of 2,4-azolidinedione-acetic acids derivatives. Eur J Med Chem. 2009;44(9):3627-36.

17. Tomašić T, Peterlin Mašič $L$. Rhodanine as a scaffold in drug discovery: a critical review of its biological activities and mechanisms of target modulation. Expert Opin Drug Discov. 2012;7(7):549-60.

18. Lesyk R, Zimenkovsky B, Atamanyuk D, Jensen F, Kieć-Kononowicz $K$, Gzella A. Anticancer thiopyrano[2,3-d][1,3]thiazol-2-ones with norbornane moiety. Synthesis, cytotoxicity, physico-chemical properties, and computational studies. Bioorg Med Chem. 2006;14(15):5230-40.

19. Lozynskyi A, Zimenkovsky B, Nektegayev I, Lesyk R. Arylidene pyruvic acids motif in the synthesis of new thiopyrano [2,3-d]thiazoles as potential biologically active compounds. Heterocycl Commun. 2015; 21(1):55-9.

20. Zelisko N, Atamanyuk D, Vasylenko O, Bryhas A, Matiychuk V, Gzella A, Lesyk R. Crotonic, cynnamic, and propiolic acids motifs in the synthesis of thiopyrano [2,3-d][1,3]thiazoles via hetero-Diels-Alder reaction and related tandem processes. Tetrahedron. 2014; 70(3):720-9.

21. Kaminskyy D, Vasylenko O, Atamanyuk D, Gzella A, Lesyk R. Isorhodanine and thiorhodanine motifs in the synthesis of fused thiopyrano [2,3-d][1,3]thiazoles. Synlett. 2011; 10: $1385-8$.

22. Lozynskyi A, Zimenkovsky B, Lesyk R. Synthesis and anticancer activity of new thiopyrano[2,3-d]thiazoles based on cinnamic acid amides. Sci Pharm. 2014; 82(4):723-33.
23. Molyneux $P$. The use of the stable free radical diphenylpicrylhydrazyl (DPPH) for estimating antioxidant activity. Songklanakarin J Sci Technol. 2004; 26(2):211-9.

24. Winter CA, Risley EA, Nuss GW. Carrageenin-induced edema in hind paw of the rat as an assay for antiiflammatory drugs. Proc Soc Exp Biol Med. 1962;111:544-7.

25. Kontogiorgis C, Hadjipavlou-Litina D. Biological evaluationof several coumarin derivatives designed as possible antiinflammatory. antioxidants agents. $J$ Enzymol Inhib Med Chem. 2003; 18(1):63-9.

26. Weber V, Rubat C, Duroux E, Lartigue C, Madesclaire M, Coudert $P$. New 3- and 4-hydroxyfuranones as anti-oxidants and anti-inflammatory agents. Bioorg Med Chem. 2005;13 (14):4552-64.

27. Panetta JA, Shadle JK, Phillips ML, Benslay DN, Ho PP. 4-Thiazolidinones, potent antioxidants, as antiinflammatory agents. Ann N Y Acad Sci. 1993;696:415-6.

28. Nijveldt RJ, van Nood E, van Hoorn DE, Boelens $P G$, van Norren $K$, van Leeuwen PA. Flavonoids: a review of probable mechanisms of action and potential applications. $A m J$ Clin Nutr. 2001;74(4):418-25.

29. Murota K, Terao J. Antioxidative flavonoid quercetin: implication of its intestinal absorption and metabolism. Arch Biochem Biophys. 2003;417(1):12-7.

30. Arora A, Nair MG, Strasburg GM. Structure-activity relationships for antioxidant activities of a series of flavonoids in a liposomal system. Free Radic Biol Med. 1998;24(9): 1355-63.

\section{Скринінг антиоксидантної та протизапальної активності похідних тіопірано[2,3-d]тіазолу}

А. В. Лозинський, Д. В. Камінський, Х. Б. Романчишин, Н. Г. Семенців, В. В. Огурцов, I. О. Нектегаєв, Р. Б. Лесик

Мета даного дослідження полягала у вивченні антиоксидантної та антиексудативної активності похідних тіопірано $[2,3-d]$ тіазолу одержаних на основі амідів коричної кислоти. Методи. Органічний синтез; спектральні методи; оцінка радикал поглинаючої (DPPH тест) та антиексудативної активностей (карагенінової модель набряку лапи щура). Результати. Проведено визначення радикал поглинаючої та антиексудативної активності амідів 2-оксо-5феніл-7-арил(гетерил)-3,7-дигідро-2H-тіопірано[2,3- $d]$ тіазол-6-карбонових кислот. Серед тестованих сполук rel$(5 R, 6 S, \quad 7 S)$ - $N$-(4-метилфеніл)-7-(4-метилфеніл)-2-оксо-5феніл-3,5,6,7-тетрагідро-2H-тіопірано[2,3-d]тіазол-6карбоксамід характеризувався максимальними значеннями обох видів активності. Отримані дані, очевидно, свідчать про виражений вплив метильних груп (у фенільних фрагментах) на реалізацію протизапального та антиоксидантного ефектів та дозволяють припустити антирадикальний механізм протизапальної активності сполук даного ряду. 
Висновки. Встановлено протизапальну та антирадикальну активності ряду тіопірано[2,3-d]тіазолів, ідентифіковано сполуки з високим рівнем активності та проаналізовані деякі аспекти взаємозв'язку структура-активність.

К л юч о в і с с о в а: тіопірано[2,3- $d]$ тіазоли, антиоксидантна, антиексудативна активність.

\section{Скрининг антиоксидантной}

и противовоспалительной активности

производных тиопирано[2,3-d]тиазола

А. В. Лозинский, Д. В. Каминский,

Х. Б. Романчишин, Н. Г. Семенцив, В. В. Огурцов,

И. А. Нектегаев, Р. Б. Лесык

Цель данного исследования заключалась в изучении антиоксидантной и антиэкссудативной активности производных тиопирано[2,3-d] тиазола полученых на основе амидов коричной кислоты. Методы. Органический синтез; спектральные методы; оценка радикал поглощающей (DPPH тест) и антиэкссудативной активностей (карагениновая модель отека лапы крысы). Результаты. Проведено иссле- дование радикал поглощающей активности и антиэкссудативного активности амидов 2-оксо-5-фенил-7-арил (гетерил)- 3,7-дигидро-2H-тиопирано[2,3-d]тиазол-6-карбоновых кислот. Среди испытуемых соединений rel-(5R,6S,7S)- $N$ (4-метилфенил)-7-(4-метилфенил)-2-оксо-5-фенил-3,5,6,7тетрагидро- $2 H$-тиопирано[2,3- $d]$ тиазол-6-карбоксамид характеризировался максимальными значениями обоих видов активности. Полученные данные, по-видимому, свидетельствуют о выраженном влиянии метильных групп (в фенильных фрагментах) на реализацию противовоспалительного и антиоксидантного эффектов и позволяют предположить антирадикальний механизм противовоспалительной активности соединений данного ряда. Выводы. Установлено противовоспалительную и антирадикальную активности ряда тиопирано[2,3-d]тиазолов, идентифицировано соединения с высоким уровнем активности, а также проанализированы некоторые аспекты взаимосвязи структура-активность.

Кл юч е в ы е с с о в а: тиопирано[2,3-d]тиазолы, антиоксидантная, антиэкссудативная активность.

Received 17.01.2015 